\title{
Statyba
}

\section{THE ESTIMATION METHODS OF MICROFILLERS INFLUENCE ON CEMENT STONE PROPERTIES}

\section{J. Deltuva \& Ž. Rudžionis}

To cite this article: J. Deltuva \& Ž. Rudžionis (1997) THE ESTIMATION METHODS OF MICROFILLERS INFLUENCE ON CEMENT STONE PROPERTIES, Statyba, 3:10, 69-75, DOI: 10.1080/13921525.1997.10531686

To link to this article: https://doi.org/10.1080/13921525.1997.10531686

曲 Published online: 26 Jul 2012.

Submit your article to this journal

III Article views: 55 


\section{MIKROUŽPILDU ITAKOS CEMENTINIO AKMENS SAVYBĖMS ANALITINIO IVERTINIMO PRINCIPAI}

\section{J. Deltuva, ̌̌. Rudžionis}

\section{Ivadas}

Mikroužpildai gali būti naudojami cemento granuliometrinei sudéčiai pagerinti, tešlos tūriui padidinti, ar kitai specialiai paskirčiai. Betonų mikroužpildai yra įvairios dispersinès medžiagos. Dažniausiai tai būna ịvairios tinkamai paruoštos gamybos mineralinès atliekos arba specialiai perdirbtos ir iki reikiamo smulkumo susmulkintos uolienos. Pagal aktyvumą mikroužpildus galima skirstyti $\mathfrak{i}$ tris grupes: chemiskai aktyvius, inertinius ir latentinius. Chemiškai aktyvūs mikroužpildai, dažniausiai turintys daugiau kaip 50\% amorfinio $\mathrm{SiO}_{2}$, dalyvauja cemento kietèjimo procese. Prie ju priskiriama malta opoka, trepelis, pelenai, ferosilicio gamybos atliekos ir kt. Jų aktyvumas priklauso nuo dispersiškumo ir $\mathrm{SiO}_{2}$ kristalingumo laipsnio. Taip pat kuo didesnis šiu mikroužpildy dispersiškumas ir kuo mažesnis $\mathrm{SiO}_{2}$ kristalingumo laipsnis, tuo aktyviau jie sudaro papildomus kalcio hidrosilikatus sąveikaudami su is cemento tešlos išsiskyrusiu $\mathrm{Ca}(\mathrm{OH})_{2}$. Chemiškai reaguoja tik paviršinè aktyviujų mikroužpildų dalis, o kita didesnioji grūdelių dalis lieka nesureagavusi.

Antrajai grupei - inertiniams mikroužpildams priskiriami dolomitas, granitas, is dalies maltas smèlis, pigmentai ir ịvairios kitos dispersinès medžiagos. Šios grupès mikroužpildai dažniausiai visai nereaguoja su cementu arba jų sąveika nepastebima.

Latentiniai mikroužpildai yra tokie, kurie turi vadinamujų paslèptų reikalingu sužadinimo, rišimosi savybių. Tai dauguma metalurginių šlakų.

Mikroužpildy dedama i betono mišinius struktūrai pagerinti ir rišamosioms medžiagoms sutaupyti. Mokslinių tyrimų autoriai [1,2] teigia, kad betony gamyboje cemento su mikroužpildais mišinys gali būti interpretuojamas kaip mažesnio aktyvumo portlandcementis, tik jo aktyvumas mažesnis proporcingai mikroužpildy kiekiui. Kity autoriu darbuose $[3,4]$ nurodoma, kad žemų ir vidutinių markiu betonuose mikroužpildy priedas leidžia efektyviau išnaudoti cementą, nes pagerinama užpildų granuliometrinè sudètis. Daugelis tyrinètojų apsiriboja galimybe naudoti inertinius mikroužpildus tik žemo ir vidutinio stiprumo betonams.

Šiuo metu vis daugiau dèmesio skiriama chemiškai aktyviems mikroužpildams ir ju naudojimui stipriesiems betonams. Šie mikroužpildai cheminès reakcijos metu jungiasi su laisvu kalcio hidroksidu, sudarydami stabilią kalcio hidrosilikato formą CSH, be to, aktyviai dalyvauja reakcijoje su sarmais ir laisvais $\mathrm{CA}^{+2}$ jonais. Kalcio hidrosilikatas, susidaręs iš amorfinio $\mathrm{SiO}_{2}$ ir $\mathrm{Ca}(\mathrm{OH})_{2}$, yra kitokios struktūros ir turi kitokias savybes nei kalcio hidrosilikatai, susidarę iš portlandcemencio mineralų. Jų tankis truputi mažesnis už hidrosilikatų, susidariusių iš portladcemenčio mineralu $[5,6]$. Teigiama šiu mikroužpildy itaka yra tokia, kad jie reaguodami su $\mathrm{Ca}(\mathrm{OH})_{2}$ sudaro stabilesnius kalcio hidrosilikatus. Tinkamas šių mikroužpildų priedas betonuose leidžia mažinti cemento sąnaudas, didina betono stiprumą, tankị, pagerina jo kitas savybes.

Ivairių mokslininku atlikti mikroužpildų betonuose tyrimai patvirtina jų naudingumą, taciau V. Solomatovas ir kt. nurodo [7], kad iki Siol néra rasta funkcinès priklausomybès tarp mikroužpildy kiekio, dispersiškumo, aktyvumo ir betono ar cemento savybiu kitimo.

\section{Mikroužpildų ir cemento mišinio santykinio tankio ir granuliometrinès sudèties optimizavimo principai}

Vienas iš galimų büdų ịvertinti mikroužpildu itaką cemento ir betono gaminiams yra struktūrinių elementu metodas. Jis leidžia ivertinti sudetingu 
heterogeninių medžiagų makrostruktūrą ir jų savybes [8]. Tyrimai rodo, kad heterogeninès medžiagos struktūrinis elementas yra mažiausias medžiagos narvelis, aproksimuotas i taisyklingos geometrinès formos erdvinį kūną, ị kurio sudètị įeina visi komponentai tokiomis pat proporcijomis, kokiomis jie esti visame tūryje. Struktūrinio elemento matmenis apriboja kietujjų komponentų stambesniujų grūdelių vidutinis skersmuo, nes šios dalelès sudaro struktüriniu elementų branduolius. Smulkesniosios dalelès bei jungiančioji fazè (skystoji, amorfinè ar dujine) sudaro branduoliu gaubiantiji sluoksni. Struktūrinių elementų metodas sudaro sąlygas netvarkingą medžiagų struktūrą pakeisti taisyklinga, supaprastinti analitini bei grafinį jos aprašymą, sudaryti medžiagu persiformavimo skaičiavimo schemas.

Laikantis polifrakcinių užpildų mišinių vienareikšmès stambiujų ir smulkiujų dalelių sampratos ir jų tūriu santykio, t.y. kad stambiosios dalelès, kurios sudaro $50 \%$ mišinio tūrio, o smulkiosios dalelès - visą kitą tūrị, iš daugelio eksperimentinių tyrimų buvo gauta tokia analitiné biriuju medžiagy santykinio tankio apskaičiavimo funkcinè priklausomybè:

$$
\rho_{s}=a \cdot \ln (D / d)+b,
$$

čia: $\rho_{\mathrm{s}}$ - santykinis polifrakcinès biriosios medžiagos tankis;

$D$ - stambiuju daleliy vidutinis skersmuo, $\mathrm{mm}$;

$d$ - smulkiujų dalelių vidutinis skersmuo, $\mathrm{mm}$;

$a$ - koeficientas, pagal tuštumy tarp stambaus užpildo dalelių užpildymo smulkiomis dalelemis laipsni;

$b$ - stambiujų dalelių santykinis tankis.

Iš funkcinès priklausomybès (1) pastebima, kad didejjant polifrakcinio mišinio $D / d$ santykiui, dideja jo santykinis tankis. Sudarant mišini iš dviejų ar daugiau polifrakciniu komponenty ir proporcingai keičiant ju santyki, gaunamas skirtingo tankio mišinys. Norint rasti didžiausią mišinio tankị ir nustatyti polifrakcinio misinio, t.y. mikroužpildo ir cemento optimalią sudètí, būtina žinoti tokius pradinius duomenis: cemento ir mikroužpildo granuliometrines sudètis bei ju santykinius tankius. Keičiant mikroužpildo kiekį nuo $0 \%$ iki $100 \%$ cemento masès apskaičiuojama mišinio granuliometrinè sudètis pagal šią formulę:

$$
\mathrm{C}_{i}=\frac{\lambda A_{i} \rho_{c}+(1-\lambda) B_{i} \rho_{m}}{\lambda \rho_{c}+(1-\lambda) \rho_{m}}
$$

čia: $\lambda$ - cemento masès dalis mišinyje (optimizuojant granuliometrinę sudèti, $\lambda$ buvo keičiama pasirinktu žingsniu nuo $0 \mathrm{iki} 1$ ); $\mathrm{C}_{i}-$ mišinio dalinè liekana ant i-ojo sieto, $\% ; A_{i}$ - cemento daliné liekana ant i-ojo sieto, $\% ; B_{i}$ - mikroužpildo dalinè liekana ant i-ojo sieto, $\% ; \rho_{c}$ ir $\rho_{m}$ - atitinkamai cemento ir mikroužpildo tankis, $\mathrm{kg} / \mathrm{m}^{3}$.

Išbiras per kiekvieną iš sietu apskaičiuojame pagal formulę:

$$
I_{i}=100-\sum_{n=1}^{i} C_{i},
$$

cia: $I_{i}$ - išbiros per i-aji sietą, \%.

Bet kuriai $\lambda$ reikšmei gaunama skirtinga misinio granuliometrinè sudétis, kurios išbirų kitimo priklausomybè nuo jų stambumo aprašoma šia formule:

$F_{I}(x, \lambda)=I_{i-1}(\lambda)+\left(x-d_{i-1}\right) \frac{I_{i}(\lambda)-I_{i-1}(\lambda)}{d_{i}-d_{i-1}}$ kai $\left(d_{i-1}<x\right) \cdot\left(x<d_{i}\right)$,

čia: $I_{i}$ ir $I_{i-1}-$ išbiros per i-uosius sietus, $\% ; d_{i}$ ir $d_{i-1}$ - sietu akeliy matmenys, mm; $x$ - ieskomy stambiujų ir smulkiuju dalelių vidutiniai matmenys, kai išbiry dydžio reikšmè $F_{I}(x, \lambda)$ stambiosioms dalelèms lygi $75 \%$, o smulkiosioms $-25 \%$.

Irašius $\mathfrak{i}$ formulę $(4) F_{I}(x, \lambda)$ reikšmę 75 ir išsprendus lygti gaunamas $\mathrm{x}$ sprendinys, atitinkantis mišinio stambiujų dalelių vidutini diametrą $D$, o įrašius $F_{I}(x, \lambda)=25-x$ sprendinys atitinka mišinio smulkiujų dalelių diametrą $d$.

Apskaičiavus $\lambda$ pasirinktu žingsniu pagal formulę (1) randama didžiausioji santykinio tankio reikšmè, t.y. $\left.\rho_{s}\left(\lambda_{0}\right)>\rho_{s}\left(\lambda_{i}\right)\right)$. Apskaiciuotoji $\lambda_{0}$ reikšmé rodo optimaly komponenty santykị, norint gauti didžiausią mišinio santykinị tankị. Kadangi šiam matematiniam uždaviniui reikia daug skaiciavimu, ypatingai tais atvejais, kai norima gauti tikslius rezultatus, pasirinkus mažą $\lambda$ žingsnį buvo sudaryta biriųju mišinių santykinio tankio optimizavimo kompiuteriu programa. Skirtingo stambumo mikroužpildai betono mišinyje turi skirtingas funkcijas. Todèl mikroužpildus pagal stambumą ir jų veiką betono mišinių savybèms sutartinai galima skirstyti $\mathfrak{i}$ tokias grupes: stambius, vidutinio stambumo ir smulkius. 
1 lentelè. Cemento ir mikroužpildų mišinio skaičiuojamosios ir eksperimentinès struktūrinès charakteristikos Table 1. Calculating and experimental structural characteristics of cement and microfillers mix

\begin{tabular}{|c|c|c|c|c|c|c|c|c|}
\hline \multirow[b]{2}{*}{$\begin{array}{l}\text { Eil. } \\
\text { Nr. }\end{array}$} & \multirow{2}{*}{$\begin{array}{l}\text { Priedo } \\
\text { atmaina }\end{array}$} & \multirow{2}{*}{$\begin{array}{l}\text { Priedo kiekis } \\
\text { cemento } \\
\text { maseje, } \%\end{array}$} & \multicolumn{4}{|c|}{ Skaičiuojamieji duomenys } & \multirow{2}{*}{$\begin{array}{c}\begin{array}{c}\text { Eksperimen- } \\
\text { tiniai } \\
\text { duomenys }\end{array} \\
\rho_{s}\end{array}$} & \multirow{2}{*}{$\begin{array}{c}\begin{array}{c}\text { Santykine } \\
\text { paklaida }\end{array} \\
\%\end{array}$} \\
\hline & & & $d, \mu \mathrm{m}$ & $D, \mu \mathrm{m}$ & $D / d$ & $\rho_{s}$ & & \\
\hline 1 & - & 0 & 3.3 & 15.4 & 4.739 & 0.623 & 0.624 & 0.23 \\
\hline 2 & \multirow{4}{*}{$\begin{array}{c}\text { Granito } \\
\text { dulkès, } \\
\mathrm{s}=297.5 \\
\mathrm{~m}^{2} / \mathrm{kg} \\
\end{array}$} & 3.29 & 3.2 & 15.5 & 4.829 & 0.624 & 0.650 & 4.01 \\
\hline 3 & & 7.24 & 3.2 & 15.6 & 4.941 & 0.626 & 0.641 & 2.35 \\
\hline 4 & & 11.23 & 3.1 & 15.7 & 5.058 & 0.627 & 0.643 & 2.44 \\
\hline 5 & & 28.69 & 2.9 & 16.2 & 5.666 & 0.634 & 0.637 & 0.41 \\
\hline$\overline{6}$ & \multirow{4}{*}{$\begin{array}{c}\text { Granito } \\
\text { dulkès, } \\
\mathrm{s}=109.1 \\
\mathrm{~m}^{2} / \mathrm{kg}\end{array}$} & 14 & 3.5 & 19.0 & 5.466 & 0.632 & 0.652 & 3.08 \\
\hline 7 & & 28.5 & 3.7 & 23.3 & 6.279 & 0.641 & 0.670 & 4.36 \\
\hline 8 & & 43.8 & 4.0 & 27.9 & 6.974 & 0.647 & 0.671 & 3.48 \\
\hline 9 & & 59.7 & 4.5 & 33.1 & 7.373 & 0.651 & 0.687 & 5.30 \\
\hline 10 & \multirow{3}{*}{$\begin{array}{c}\begin{array}{c}\text { Granito } \\
\text { dulkès, } \\
\mathrm{s}=37.8 \mathrm{~m}^{2} / \mathrm{kg}\end{array} \\
\end{array}$} & 9.45 & 3.7 & 20.5 & 5.615 & 0.634 & 0.653 & 3.01 \\
\hline 11 & & 19.15 & 4.2 & 26.8 & 6.444 & 0.642 & 0.658 & 2.42 \\
\hline 12 & & 39.28 & 5.6 & 76.6 & 13.610 & 0.689 & 0.665 & 3.65 \\
\hline 13 & \multirow{4}{*}{$\begin{array}{c}\text { Maltas } \\
\text { smélis, } \\
\mathrm{s}=277 \\
\mathrm{~m}^{2} \mathrm{~kg}\end{array}$} & 3 & 3.2 & 15.6 & 4.827 & 0.624 & 0.646 & 3.40 \\
\hline 14 & & 7 & 3.2 & 15.9 & 4.948 & 0.626 & 0.654 & 4.34 \\
\hline 15 & & 12 & 3.2 & 16.4 & 5.177 & 0.629 & 0.631 & 0.41 \\
\hline 16 & & 25 & 3.1 & 18.1 & 5.884 & 0.637 & 0.655 & 2.80 \\
\hline 17 & \multirow{3}{*}{$\begin{array}{c}\text { Maltas smèlis, } \\
\mathrm{s}=110.4 \\
\mathrm{~m}^{2} / \mathrm{kg}\end{array}$} & 8 & 3.3 & 17.2 & 5.160 & 0.628 & 0.636 & 1.15 \\
\hline 18 & & 15 & 3.4 & 19.4 & 5.694 & 0.635 & 0.640 & 0.89 \\
\hline 19 & & 30 & 3.6 & 24.4 & 6.778 & 0.646 & 0.619 & 4.35 \\
\hline 20 & \multirow{3}{*}{$\begin{array}{c}\text { Maltas smèlis, } \\
\mathrm{s}=60.8 \\
\mathrm{~m}^{2} / \mathrm{kg}\end{array}$} & 10 & 3.5 & 19.4 & 5.500 & 0.632 & 0.646 & 2.03 \\
\hline 21 & & 25 & 4.0 & 27.5 & 6.854 & 0.646 & 0.643 & 0.53 \\
\hline 22 & & 40 & 4.7 & 50.3 & 10.623 & 0.674 & 0.646 & 4.36 \\
\hline
\end{tabular}

Stambūs mikroužpildai: tai mikroužpildai, stambesni už cementą ir naudingi tuo atveju, kai užpilduose stokojama smulkiagrūdès frakcijos. Granuliometrinès sudèties optimizavimo skaičiavimuose mikroužpildus, stambesnius nei $63 \mu \mathrm{m}$, tikslinga priskirti užpildams.

Vidutinio stambumo mikroužpildai yra artimo cementui smulkumo. Jų priedas yra efektyvus žemų ir vidutinių markių betonuose, norint padidinti cemento tešlos kieki mišinyje. Šie mikroužpildai taip pat gali turèti teigiamos įtakos cemento granuliometrinès sudèties pagerinimui. Todél tikslinga optimizuoti cemento ir mikroužpildo mišinio granuliometrinę sudetit.

Smulkūs ir ypatingai smulkūs mikroužpildai yra daug smulkesni už cementą, ir jų dalelès telpa tarp cemento grūdelių. Aproksimuojant cemento ir mikroužpildo grūdelius į rutulio formą ir remiantis teoriniais grūdelių maksimaliai tankaus susidèstymo skaičiavimais, buvo gautas cemento ir mikroužpildo grūdelių skersmeny santykis $d_{\mathrm{c}} / d_{m}$, kuris ir apibūdina jų smulkumo santykị.

Skaičiuojant cemento tešlos struktūrinių elementy charakteristikas, ypatingai smulkiu mikroužpildụ tūrị tikslinga priskirti prie vandens tūrio, nes mišinio tankio atžvilgiu jie atlieka adekvačią (lygiavertę) funkciją - užpildo tuštumas tarp cemento grūdelių.

Teoriniams skaičiavimams patikrinti buvo atlikti eksperimentiniai tyrimai, dedant ịvairaus stambumo mikroužpildų í cementą. Mikroužpildų ir cemento granuliometrinès sudètys buvo nustatytos lazeriniu granuliometru „Fritsch Analizete 22”. Remiantis gautais tyrimo rezultatais buvo apskaiciuotos cemento ir mikroužpildy struktūrinès charakteristikos: stambesniujų dalelių vidutinis diametras $D$, smulkesniujuc daleliu vidutinis diametras $d$ ir santykinis mišinio tankis $\rho_{s}$. Duomenys pateikti 1 lentelèje. 
Biriuju medžiagų apskaičiuotas santykinis tankis $\rho_{s}$ apibūdina sutankintos būklès medžiagą. Eksperimentiniuose tyrimuose bandiniai buvo sutankinami presuojant. Presavimo slègis ir vandens kiekis buvo parinktas skaičiavimais ir ieškomaisiais eksperimentais. Ju metu nustatyta, kad esant vandens kiekiui, reikalingam gauti normalaus tirštumo tešlą, ir 20 $\mathrm{MPa}$ presavimo slègiui, gaunamas mišinio sutankinimas artimas maksimaliam. Eksperimentiniai tyrimo rezultatai (santykinis mišinio tankis be vandens) pateikti 1 lenteleje. Palyginus gautus eksperimentinius duomenis ir skaičiavimo rezultatus, galima pastebèti jų pakankamą tapatumą.

Iš gautų tyrimo ir skaiciavimo rezultaty matyti, kad esant didesniam cemento ir mikroužpildo smulkumo skirtumui gaunamas ryškesnis mišinio santykinio tankio padidèjimas. Norint gauti geresnès granuliometinès sudėties mišini, mikroužpildą reikia parinkti kelis kartus stambesnị arba smulkesni už cementą. Artimas cemento smulkumui mikroužpildas neturi didelès reikšmès granuliometrinès sudèties ir tankio pagerinimui, tačiau ji efektyvu naudoti kartu su aukštos klasès cementu žemų ir vidutinių klasių betonams. Siuose betonuose paprastai stokojama cemento tešlos, t.y. užpildų mišnio tuštumų perpildymo cemento tešla koeficientas $\beta<1$. Čia:

$$
\beta=\frac{\varphi_{\text {c.t. }}}{1-\rho_{\text {s.u. }}},
$$

$\varphi_{\text {c.t. }}$ - cemento tešlos tūrinè koncentracija vieneto dalimis $1 \mathrm{~m}^{3}$ betono mišinio; $\rho_{s . u}$ - santykinis betono užpildų mišinio tankis .

Padidinus cemento tešlos tūrị mikroužpildais, $\beta$ skaičiuojamas taip:

$$
\beta=\frac{\varphi_{c . t .}+\varphi_{m .}}{.1-\rho_{\text {s.u. }}},
$$

čia: $\varphi_{m}-$ mikroužpildo tūrinė koncentracija vieneto dalimis $1 \mathrm{~m}^{3}$ betono mišinio.

Šiuo atveju mikroužpildas, užpildydamas tuštumas tarp užpildo dalelių, padidina betono mišinio tanki, pagerina kitas jo fizikines mechanines savybes.

\section{Presuotojo cementinio akmens su mikroužpildo priedu savybiu ivertinimo principai}

Ivairių mokslininku atlikti betono ir cementinio akmens fizikinių ir mechaninių savybių tyrimai $[1,9$,
10] leidžia teigti, kad vienas iš svarbiausių cementinio akmens ir betono struktūros rodiklių yra V/C santykis. Jis turi didelès itakos cementinio akmens poringumui ir mechaninèms savybèms.

Pakeičiant dali cemento ivairaus smulkumo mikroužpildu, greta V/C santykio svarbu ịvertinti ir inertinio mikroužpildo itaką cementinio akmens tankiui. Remiantis A.Šeikino ir kt. [9] išvesta cementinio akmens santykinio tankio skaičiavimo formule:

$$
\rho_{\text {s.c.a. }}=\frac{1+0.23 \alpha \rho_{c .}}{1+\rho_{c .} V / C},
$$

čia: $\alpha$. - cemento hidratacijos laipsnis; $\rho_{c}$. - cemento tankis, $\mathrm{g} / \mathrm{cm}^{3} 0,23$ - $1 \mathrm{~g}$ cemento chemiškai prijungto vandens masé, esant hidratacijos laipsniui $\alpha=1 ; \mathrm{V} / \mathrm{C}$ vandens ir cemento santykis.

Remiantis (7) formule buvo išvesta formule skaičiuoti cementinio akmens su inertiniu mikroužpildu santykiniam tankiui:

$$
\rho_{\text {s.c.a.m. }}=\frac{1 / \rho_{c}+0.23 \alpha+M / \rho_{m}}{1 / \rho_{c}+V / C+M / \rho_{m}} X_{1},
$$

čia: $M$ - mikroužpildo dalis cemente; $\rho_{m}$ - mikroužpildo tankis, $\mathrm{g} / \mathrm{cm}^{3} ; X_{1}$ - koeficientas, îvertinantis cementinio akmens tankio su mikroužpildais padidèjimą, nes dalis ju telpa tarp cemento dalelių. $X_{1}$ apibūdina mikroužpildo ir cemento tankių santykí.

$$
X_{1}=\frac{\rho_{\text {s.m. }}}{\rho_{\text {s.c. }}},
$$

$\rho_{s . m .}$ - cemento ir mikroužpildo sauso mišinio santykinis tankis; $\rho_{\text {s.c. }}$ - sausojo cemento santykinis tankis.

Šiuo metu daug kas remiasi išvesta cementinio akmens stiprumo ir V/C santykio empirine priklausomybe, tačiau pastebèta, kad ji galioja tik absoliučiai sutankintam cementiniam akmeniui ir neleidžia įvertinti tankio pokyčio ịtakos cementinio akmens stiprumui.

Siekiant aprašyti mikroužpildų itaką cementinio akmens stiprumui, buvo remtasi T. Pauerso [11] išvesta priklausomybe:

$$
R_{c}=A \rho_{\text {s.c.a. }}^{n},
$$

čia: $A$ ir $n$ - empiriniai koeficientai; $\rho_{\text {s.c.a. }}$ cementinio gelio tūrio santykis su viso gelio ir tuštumų tūriu; $R_{c}$ - cementinio akmens stipris.

Šios priklausomybès empirinių koeficienty reikšmes $A$ ir $n$ įvairūs mokslininkai pateikia skirtingas. Pastebèta, kad jų reikšmès priklauso nuo 
cemento cheminès sudèties ir sutankinimo laipsnio. Remiantis kai kuriu mokslininku teiginiu, kad inertiniai mikroužpildai mažina cemento aktyvumą proporcingai ju kiekiui, ir atsižvelgiant $i$ ju ịtaką cementinio mišinio tankiui buvo gauta funkciné priklausomybè cementinio akmens su mikroužpildo priedu stiprio skaičiavimui:

$$
R_{c}=130 \rho_{\text {s.c.a.m. }}^{2.8}\left(1-\varphi_{m}\right),
$$

cia: $R_{c}$-cementinio akmens su mikroužpildu stipris, Mpa; $\rho_{\text {s.c.a.m. }}$ - cementinio akmens su mikroužpildo priedu santykinis tankis; $\varphi_{m}$ - mikroužpildo tūrinè koncentracija sausajame misinyje vieneto dalimis.

Funkcinèms priklausomybems (8) ir (11) patikrinti buvo pagaminti ir išbandyti bandiniai. Gauti rezultatai palyginti su skaičiuojamaisiais ir pateikti 2 lentelèje.

Aktyvių mikroužpildų ịtakos cementinio akmens savybèms ir (8) bei (11) funkcijoms patikrinti buvo atlikti kiti eksperimentiniai tyrimai. $\{$ cementinị skiedinį buvo dedamas iqvairus kiekis ferosilicio gamybos atlieku (mikrodulkiu). Bandiniai buvo presuojami 20 MPa slègiu, esant V/C santykiui, reikalingam normalaus tirštumo tešlai gauti. Eksperimentiniams tyrimams naudotos mikrodulkès is Stachanovo metalurgijos kombinato (Ukraina), kuriu savitasis paviršius, nustatytas $\Pi C X-4$ prietaisu, yra $26,4 \mathrm{~m}^{2} / g$. Šioje medžiagoje silicio dioksido kiekis, nurodytas techniniame pase, buvo $92 \%$.

Pastebèta, kad mišiniai su ferosilicio gamybos atlieku priedu homogeniškesni, o suformuoti gaminiai kokybiškesni. I cementą dedant daugiau kaip $10 \%$ dulkiu ir nekeičiant $\mathrm{V} / \mathrm{C}$ santykio (nors vandens pareikalavimas ir didesnis), gaminiai susiformuoja didesnio santykinio tankio nei be priedų. Manoma, kad viena iš gaminių struktūros pagerẻjimo priežasčiu yra ta, kad presuotose sistemose pageidautinas didesnis smulkiadispersès fazès türis, dèl kurio mažèja mechaninio sukibimo ir trinties jèga tarp dalelių.

2 lentelè. Presuoto cementinio akmens su inertinio mikroužpildo priedu savybių tyrimo duomenys

Table 2. Investigation data of pressed cement stone with inert microfillers admixture

\begin{tabular}{|c|c|c|c|c|c|c|c|c|}
\hline & \multirow{2}{*}{$\begin{array}{l}\text { Priedo } \\
\text { atmaina }\end{array}$} & \multirow{2}{*}{$\begin{array}{c}\text { Priedo kiekis } \\
\text { nuo } \\
\text { cemento } \\
\text { masès, } \% \\
\end{array}$} & \multicolumn{2}{|c|}{$\begin{array}{l}\text { Eksperimentiniai } \\
\text { duomenys }\end{array}$} & \multicolumn{2}{|c|}{$\begin{array}{c}\begin{array}{c}\text { Skaičiuojamieji } \\
\text { duomenys }\end{array} \\
\end{array}$} & \multicolumn{2}{|c|}{$\begin{array}{c}\text { Santykinè paklaida, } \\
\%\end{array}$} \\
\hline $\begin{array}{l}\text { Eil. } \\
\text { Nr. }\end{array}$ & & & $\begin{array}{c}\text { Santyki- } \\
\text { nis tankis }\end{array}$ & $\begin{array}{l}\text { Stipris, } \\
\text { MPa }\end{array}$ & $\begin{array}{c}\text { Santyki- } \\
\text { nis tankis }\end{array}$ & $\begin{array}{c}\text { Stipris, } \\
\text { MPa }\end{array}$ & $\begin{array}{c}\text { Santykini } \\
\text { o tankio } \\
\end{array}$ & Stiprio \\
\hline 1 & - & 0 & 0.898 & 79.9 & 0.887 & 93.02 & 1.20 & 17.75 \\
\hline 2 & \multirow{4}{*}{$\begin{array}{c}\text { Granito } \\
\text { dulkès, } \\
\mathrm{s}=297.5 \\
\mathrm{~m}^{2} / \mathrm{kg}\end{array}$} & 3.29 & 0.938 & 92 & 0.921 & 99.76 & 1.87 & 8.44 \\
\hline 3 & & 7.24 & 0.921 & 94 & 0.910 & 92.74 & 1.11 & 1.34 \\
\hline 4 & & 11.23 & 0.910 & 79.2 & 0.900 & 86.01 & 1.06 & 8.60 \\
\hline 5 & & 28.69 & 0.850 & 55.4 & 0.857 & 60.18 & 0.83 & 8.63 \\
\hline 6 & \multirow{4}{*}{$\begin{array}{c}\text { Granito } \\
\text { dulkès, } \\
\mathrm{s}=109.1 \\
\mathrm{~m}^{2} / \mathrm{kg}\end{array}$} & 14 & 0.900 & 81.5 & 0.901 & 83.60 & 0.15 & 2.57 \\
\hline 7 & & 28.5 & 0.863 & 61.8 & 0.873 & 63.62 & 1.20 & 2.94 \\
\hline 8 & & 43.8 & 0.818 & 45 & 0.838 & 44.55 & 2.41 & 1.00 \\
\hline 9 & & 59.7 & 0.789 & 24.5 & 0.797 & 27.76 & 1.01 & 13.31 \\
\hline 10 & \multirow{3}{*}{$\begin{array}{c}\text { Granito } \\
\text { dulkès, } \\
s=37.8 \mathrm{~m}^{2} / \mathrm{kg}\end{array}$} & 9.45 & 0.918 & 100 & 0.917 & 92.35 & 0.08 & 7.65 \\
\hline 11 & & 19.15 & 0.888 & 79.8 & 0.899 & 78.12 & 1.31 & 2.10 \\
\hline 12 & & 39.28 & 0.810 & 54.2 & 0.905 & 59.72 & 11.75 & 10.18 \\
\hline 13 & \multirow{4}{*}{$\begin{array}{l}\text { Maltas } \\
\text { smélis, } \\
\mathrm{s}=277 \\
\mathrm{~m}^{2} / \mathrm{kg} \\
\end{array}$} & 3 & 0.926 & 105 & 0.923 & 100.82 & 0.30 & 3.98 \\
\hline 14 & & 7 & 0.932 & 112 & 0.913 & 93.63 & 2.05 & 16.41 \\
\hline 15 & & 12 & 0.885 & 88 & 0.902 & 85.63 & 1.94 & 2.70 \\
\hline 16 & & 25 & 0.875 & 68 & 0.875 & 67.13 & 0.05 & 1.28 \\
\hline 17 & \multirow{3}{*}{$\begin{array}{c}\text { Maltas smèlis, } \\
\mathrm{s}=110.4 \\
\mathrm{~m}^{2} / \mathrm{kg}\end{array}$} & 8 & 0.896 & 86 & 0.914 & 93.10 & 2.03 & 8.25 \\
\hline 18 & & 15 & 0.884 & 83 & 0.902 & 82.78 & 2.02 & 0.26 \\
\hline 19 & & 30 & 0.810 & 57 & 0.874 & 62.35 & 7.82 & 9.39 \\
\hline 20 & \multirow{3}{*}{$\begin{array}{c}\text { Maltas smèlis, } \\
\qquad \mathrm{s}=60.8 \\
\mathrm{~m}^{2} / \mathrm{kg}\end{array}$} & 10 & 0.902 & 102 & 0.912 & 90.54 & 1.15 & 11.24 \\
\hline 21 & & 25 & 0.846 & 71 & 0.887 & 69.71 & 4.80 & 1.81 \\
\hline 22 & & 40 & 0.800 & 52 & 0.877 & 54.07 & 9.62 & 3.98 \\
\hline
\end{tabular}


Greta teigiamo ferosilicio gamybos atlieky mechaninio poveikio betono mišiniams, jos yra chemiškai aktyvios ir intensyviai dalyvauja rekcijose su cemento akmens hidratacijos produktais. Atlikus cementiniy bandiniy su ferosilicio gamybos atliekomis rentgenografinę analizę pastebèta, kad cemento hidratacijos metu $\mathrm{SiO}_{2}$ jungiasi su laisvu kalcio hidroksidu, sudarydamas stabilius dispersinius kalcio hidrosilikatus.

Nors naujadarai iš mikrodulkių yra mažesnio tankio, tačiau nustačius cementinio akmens absoliutinị tankį matyti, kad jis didèja, didèjant ferosilicio gamybos atliekų kiekiui mišinyje. Tai galima paaiškinti tuo, jog naujadarai is mikrodulkiu su kalcio šarmu yra dispersiniai ir užpildo tarpus tarp cemento dalelių ir lieka hidratacijos produktuose.

Ferosilicio gamybos atlieku priedas iki $10 \%$ cemento masès didina cementinio akmens stiprumą $54,7 \%$ ir turi teigiamos iztakos betono fizikinèms ir mechaninėms savybėms. Gaminiai atsparesni atmosferos poveikiams. Be to, presuotose sistemose dèl didelio jų tankio ir mažo V/C lieka nemažai nesihidratavusių cemento dalelių. Betonuose su ferosilicio gamybos atliekomis hidratacijos produkty padaugèja 10-25\%.

[̨vertinus chemiškai aktyvil̨ mikróužpildų poveiki cemento hidratacijos produktams, buvo redukuota (8) formulè ir gauta formulè skaičiuoti cementinio akmens su šiuo mikroužpildu santykiniam tankiui:

$$
\rho_{\text {s.c.a.m. }}=\frac{1 / \rho_{c}+0.23 \alpha_{1}(1+M)+M / \rho_{m}}{1 / \rho_{c}+V / C+M / \rho_{m}} X_{1},
$$

čia: $\alpha_{1}$ - cemento ir chemiškai aktyvaus mikroužpildo mišinio hidratacijos laipsnis.

\section{Išvados}

1. Optimizuojant mikroužpildų ir cemento mišinio granuliometrinę sudètį pagal (2) ir (4) formules, o tankị ir stiprị pagal (8), (11) ir (12) formules, susidaro galimybe racionaliai išnaudoti abu komponentus, taupyti cementą ir pagerinti betono fizikinių bei mechaninių savybių rodiklius.

2. I cementą pridedant iki $10 \%$ inertinių mikroužpildų, visais atvejais padidèja ceméntinio akmens tankis iki $4,5 \%$, o stipris iki $40,2 \%$. Pridedant chemiškai aktyvių mikroužpildų (ferosilicio atliekų) 10\%, cemento akmens tankis padideja iki 7,4\%, o stipris iki $54,7 \%$. Idèjus $15-20 \%$ cemento su ferosilicio atliekomis akmens stipris prilygsta cemento be priedų stipriui.

\section{Literatūra}

1. Ю.М.Баженов. Технология бетона. Москва: Высшая школа, 1987. $415 \mathrm{c}$.

2. В.И.Саламатов, Д.Ш.Кодверова. Влияние количества наполпителя и добавок на свойства бетона и бетонной смеси / ТПИ. Ташкент, 1986. $111 \mathrm{c}$.

3. В.С.Рамачандран, В.Ф.Фельдман, М.Колитарди и др. Добавки в бетон: Справочное пособие. Москва: Стройиздат, 1988. $575 \mathrm{c}$.

4. A.Goldman, A.Bentur. The influence of microfillers on enhancement of concrete strength // Cement and concrete reseach. 1993. Vol. 23, Nr. 1, p. 963-972.

5. G.G.Carette, M.F.Pistilli. Silica fume in concrete // ACI Materials journal, 1987, Nr. 2, p. 159-167.

6. Gapesh Dadu A., Surya Prakash P.V. Efficiency of silica fume in concrete // Cement and Concrete Research, 1995, Nr. 6, p. 1273-1282.

7. В.И.Соломатов, М.К.Тахиров, Такер Шах Мд. Интенсивная технология бетонов. Москва: Стройиздат, 1989. $261 \mathrm{c}$.

8. J.Deltuva. Struktūrinių elementy metodas - priemonẻ heterogeniniu medžiagu tyrimui // Mokslas ir technika, Nr. 4, 1995.

9. А.Е.Шейкин, Ю.Е.Чеховский, М.И.Брусер. Структура и свойства цементных бетонов. Москва: Стройиздат, 1979. $343 \mathrm{c.}$

10. И.Н.Ахвердов. Основы физики бетона. Москва: Стройиздат, $1981.464 \mathrm{c}$.

11. Т.К.Пауэрс. Физическая структура портланццементного теста // Химия цемента / Под ред. Х.Ф.У.Тейлора. Москва: Стройиздат, 1969. 264 с.

Iteikta 19970507

\section{TIIE ESTIMATION METHODS OF MICROFILLERS INFLUENCE ON CEMENT STONE PROPERTIES}

\section{J. Deltuva, Ž. Rudžionis}

S u m m a r y

The concrete and cement microfillers are materials of different fineness, such as wastes of production or pulverized rocks. According to their influence on cement hardening process, they may be classified into inert microfillers or chemically active ones. The chemically active microfillers, such as silica fume, fly ashes and others, have more then $50 \%$ amorphous $\mathrm{SiO}_{2}$, that takes part in cement hardening process. Inert microfillers, such as granite, dolomite, sand dust and others, in most cases have no influence on the cement hydration.

The usage of microfillers in concrete is common, but so far no clear dependence between the quantity of added microfillers and properties of concrete has been established. One of possible ways to estimate the 
microfillers influence on the products with cement binder is the structural element method.

The structural element is the smallest cell, approximated to a spatial figure of regular form, that has all components with the same proportions, as in all the volume of heterogeneous material. The-essence of this method is to divide the mix in to bigger particles, that are named "nuclei" of structural elements and take $50 \%$ of all mix volume, and smaller particles, that form cover layers of the nuclei and make up the rest of the volume of the mix. The dependence between the relative density of loose materials and relation (1) between the diameters of the bigger and smaller particles of the structural element has been estimated. This relation is changed when microfillers are added to the cement. There is a possibility to optimize relative density by (2), (3) and (4) relations, if the granulometric composition of the cement and microfiller is known. The experimental and calculated results of this optimization are shown in Table 1.

The properties of pressed cement stone with inert microfillers admixture are presented in Table 2. Formulae for calculating the relative density (8) and compressive strength (11) of hardening cement have been estimated.

The chemically active microfillers, such as silica fume, interact with $\mathrm{Ca}(\mathrm{OH})_{2}$ and form new $\mathrm{CSH}$. The density and strength of cement stone increased after this interaction. The influence of chemically active microfillers on the relative density of the cement stone is given in (12).
The density of cement stone increases to $4.5 \%$ and strength increases to $40.2 \%$, if the quantity of inert microfillers in the cement paste reaches $10 \%$. The density of cement stone increases to $7.4 \%$ and strength increases to $54.7 \%$, if the quantity of chemically active microfillers in the cement paste reaches $10 \%$.

Juozas DELTUVA. Doctor, Associate Professor, Department of Building Materials. Kaunas University of Technology (KTU). 48 Studenty St, 3031 Kaunas, Lithuania.

In 1956 Doctor's degree (Influence of increased intensity vibration on the forming of concrete mix and its properties). In 1969-79 and 1988-95 Head of the Department of Building Materials at KTU. In 1995-97 Head of the Research Laboratory of Building Materials and Construction. Research interests: mineral raw materials, their remaking, structural analysis of heterogeneous materials.

Žymantas RUDžıONIS. Senior Assistant. Department of Building Materials. Kaunas University of Technology (KTU). 48 Studenty St, 3031 Kaunas, Lithuania.

Since 1989 at KTU laboratory of Building Materials. Since 1991 a post-graduate student at KTU. Research interests: dense decorative concrete: its production and investigations into its properties. 